\title{
Short-term Effects of Shallow Sphagnum Moss Biomass Harvesting on the Runoff Water Quality
}

\author{
Niko Silvan \\ Department of Bio-based Business and Industry, Natural Resources Institute Finland, Parkano, Finland
}

Email address:

niko.silvan@luke.fi

\section{To cite this article:}

Niko Silvan. Short-term Effects of Shallow Sphagnum Moss Biomass Harvesting on the Runoff Water Quality. International Journal of Environmental Monitoring and Analysis. Vol. 7, No. 1, 2019, pp. 34-39. doi: 10.11648/j.ijema.20190701.15

Received: April 5, 2019; Accepted: June 10, 2019; Published: June 27, 2019

\begin{abstract}
White horticultural peat is proven to be a superior growing medium. It is microbiologically active, it binds nutrients and water significantly due to its favorable cation exchange capacity and porosity. Unfortunately, horticultural peat is a very slowly renewable biomass, and good quality horticultural peat is not so common even in peatland-rich countries. Therefore, good-quality and simultaneously renewable growing media alternatives are needed. A new growing medium introduced in recent years is based on Sphagnum moss biomass. According to our results, shallow Sphagnum moss biomass harvesting extended down to a depth of not over $30 \mathrm{~cm}$ did not cause any harmful effects on watercourses during the shortterm period after harvesting. On the contrary, it is well-known that traditional peat extraction increases the leaching of suspended solids, dissolved organic carbon and nutrients, especially nitrogen and phosphorus into watercourses located downstream. The leaching of SS, DOC and nutrients from peat extraction areas is a significant local problem, since the nutrient leaching may cause enhanced eutrophication and decreased biodiversity, especially in vulnerable headwaters. Because of the probably negligible harmful effects on the water quality, Sphagnum moss biomass can be considered as a truly environmentalfriendly growing medium compared with the conventionally extracted white horticultural peat.
\end{abstract}

Keywords: Renewable Growing Medium, Sphagnum Mosses, Sphagnum Moss Biomass Harvesting, Water Quality

\section{Introduction}

Nowadays, the two primary growing media used in greenhouse cultivation are rockwool and white horticultural peat (formed from Sphagnum mosses), from which white Sphagnum peat is by far the most widely used around the world [1-3]. Unfortunately, horticultural peat is a very slowly renewable biomass. In addition, good quality horticultural peat is diminishing even in the peatland-rich countries. Therefore, good-quality and simultaneously renewable growing media alternatives are needed. A novel growing medium studied in this study is based on the living Sphagnum moss biomass and it is introduced in the studies of Silvan et al. and Kämäräinen et al. [4, 5]. Sphagnum moss biomass is planned to harvest and regrow within ca. 30 years on the same site of the peatland, and it will be harvested from the mire surface down to the maximum depth of $30 \mathrm{~cm}$ [4].

Moderate industrial scale Sphagnum moss biomass harvesting for horticultural purposes has also been carried out for instance in North America, Australia and Chile for many decades with promising results of recovery [6-9]. Sphagnum moss biomass harvesting has been carried out both during winter in snow and frost conditions (in North America) and during summer as well (in Australia) [6-8, 10]. During summertime, machinery used for Spagnum moss biomass harvesting have to be equipped with extremely broad tracks $(\geq 140 \mathrm{~cm})$, and the normal tractor pulled carts cannot generally be used for Sphagnum biomass transportation instead of caterpillar type transporting machinery [4]. Despite the challenges, Sphagnum moss biomass harvesting is likely to be carried out successfully with appropriate machinery in summer too.

For growing medium purposes, hummock-forming and some lawn species (for instance Sphagnum fuscum, $S$. rubellum, S. magellanicum and S. papillosum) are the most applicable $[5,11]$. The most successful habitats for these species are pristine nutrient-poor treeless or sparsely wooded bogs [12]. On many of forestry drained nutrient-poor and unprofitable peatlands there also exist adequate amounts of Sphagnum for harvesting purposes [12]. Due to the public 
opinion, Sphagnum moss biomass harvesting should be directed to these drained peatland areas, for which there may not be any other profitable land-use options than Sphagnum moss biomass harvesting. This is not a significant dilemma in Finland where approximately one million hectares of unprofitable drained peatlands with low forest growth remain out of the wood production. It is estimated that ca. 300000 ha from these almost million hectares could be utilised for Sphagnum moss biomass harvesting [4].

It is well-known that peat extraction with a conventional milling method highly increases the leaching of suspended solids (SS), dissolved organic carbon (DOC) and nutrients, especially nitrogen $(\mathrm{N})$ and phosphorus (P), into watercourses located downstream, mainly due to the intensive drainage and milling of the surface peat e.g. [1316]. The leaching of SS, DOC and nutrients from peat extraction areas is a significant local environmental problem, since the nutrient leaching may cause enhanced eutrophication and decreased biodiversity, especially in vulnerable headwaters [15, 17-20]. However, fortunately, Sphagnum moss biomass harvesting cannot be compared to peat extraction as a method. Since the very low ash and nutrient concentrations in living, undecomposed Sphagnum moss biomass, the shallow harvesting depth not reaching decomposed, nutrient-rich peat layers or mineral soil, and no need of drainage during Sphagnum moss biomass harvesting $[4,21]$, it is probable that the harmful effects on watercourses will remain very moderate.

The aim of this study was to: monitor and quantify the short-term effects of Sphagnum moss biomass harvesting on watercourses. We hypothetisized that the effects caused by Sphagnum moss biomass harvesting on the watercourses will remain relatively small and only short-term.

\section{Methods}

\subsection{Study Site Characteristics and Sphagnum Moss Biomass Harvesting}

The study was carried out at Tunkiosalonnneva, in Central Finland $\left(62^{\circ} 19^{\prime} \mathrm{N}, 22^{\circ} 80\right)$, over a one year from October 2009 to October 2010. Tunkiosalonneva was the first demonstration Sphagnum moss biomass harvesting area in Finland with ca. 2 hectares and ca. $2000 \mathrm{~m}^{3}$ harvested Sphagnum moss biomass (Figure 1) [22]. The study site was constructed so that the effects on water quality caused by Sphagnum moss biomass harvesting were possible to monitor, i.e. the catchment area was small with no remarkable external SS or nutrient loads (Figure 1). Tunkiosalonneva was a typical nutrient-poor forestry drained peatland in Central Finland. Ditch network at Tunkiosalonneva was sparse and partly deteriorated allowing the rise of water table level and thus favoring the recovery of Sphagnum mosses. The original mire site type of the study site was a low sedge $S$. papillosum pine fen [12]. The longterm (1987-2017) annual mean temperature of the site is ca. $3.0^{\circ} \mathrm{C}$, the annual mean precipitation is approximately 605 $\mathrm{mm}$ and the accumulative temperature sum $\left(+5^{\circ} \mathrm{C}\right)$ is ca. 1050 degree-days.

Sphagnum moss biomass was harvested in AugustSeptember 2009 from the mire surface down to a maximum depth of $30 \mathrm{~cm}$ [22]. The best harvesting period in central Finland and in normal weather conditions has been shown to be during early autumn, when the depth of water table level is the lowest, and therefore the carrying capacity of the peat soil is the highest.

\subsection{Water Quality Monitoring and Analyses}

Runoff $\left(\mathrm{l} \mathrm{s}^{-1} \mathrm{ha}^{-1}\right), \mathrm{pH}$, suspended solids (SS), dissolved organic carbon (DOC) (mg $\left.\mathrm{l}^{-1}\right)$, total nitrogen $\left(\mathrm{N}_{\text {tot }}\right)$, ammonium-nitrogen $\left(\mathrm{NH}_{4}{ }^{+}\right)$, nitrate-nitrogen $\left(\mathrm{NO}_{3}{ }^{-}\right)$, total phosphorus $\left(\mathrm{P}_{\text {tot }}\right)$ and phosphate-phosphorus $\left(\mathrm{PO}_{4}{ }^{3}\right)\left(\mu \mathrm{g} \mathrm{l}^{-1}\right)$ concentrations were monitored at the study site during October 2009-October 2010. Runoff rates were measured using triangular Thomson's $\left(90^{\circ}\right)$ measuring weir (introduced by James Thomson first time in 1859) equipped with an automatic water level recorder allowing continuous measurements. The runoff rates were measured only below of the harvesting area (lower weir), and they were assumed similar to above of the harvesting area (upper weir) (Figure 1). Water samples were taken approximately biweekly from both upper and lower measuring weirs during summertime (May-October). During winter (November-April), water samples were taken ca. monthly if there was existing runoff.

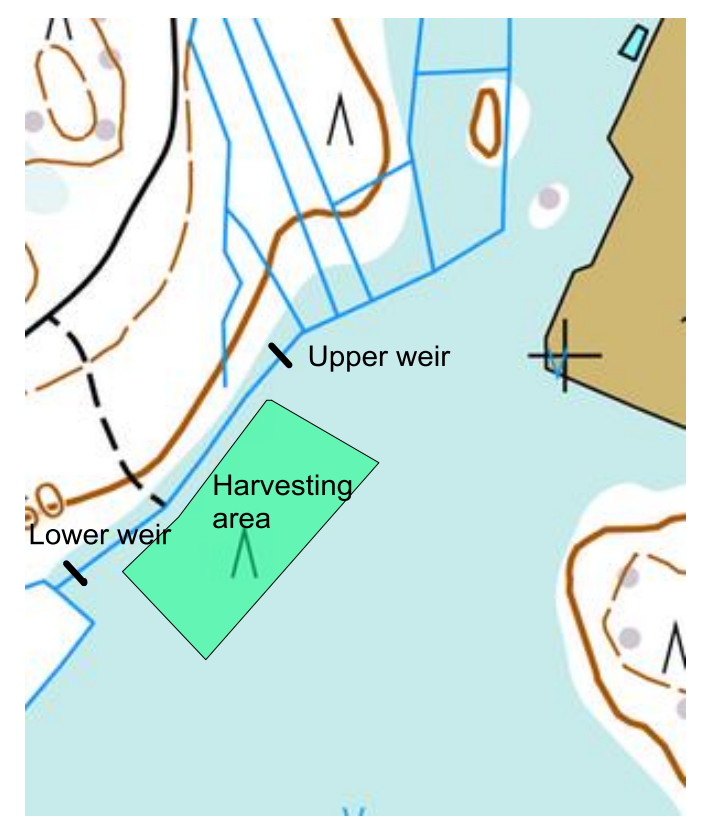

Figure 1. The schematic map of the study site.

The inflow water was discharged from a small, mainly forestry drained peatland containing catchment area upstream from the study area. We used the load from the upper catchment area (inflow water) as a background load. SS and nutrient loads from the site were determined by subtracting background load from outflow load. In this study, load from the Sphagnum moss biomass harvesting area was therefore considered as an input-output balance or as a surplus in the 
load caused by Sphagnum moss biomass harvesting.

Water samples were taken directly into $500 \mathrm{ml}$ plastic bottles from the upper and lower measuring weirs (Figure 1). Water $\mathrm{pH}$ was analysed from fresh water samples within 24 hours after sampling with Philips PW $9422 \mathrm{pH}$ meter. Prior to $\mathrm{SS}$ analysis, the samples were stored at $+5^{\circ} \mathrm{C}$, and prior to other analyses at $-20^{\circ} \mathrm{C}$. SS concentration was determined by filtering the water samples (fibre-glass, pore size $1.2 \mu \mathrm{m}$ ), and then weighing the tared filters dried at $+60^{\circ} \mathrm{C}$. The concentrations of DOC were analysed from filtered water with a Shimadzu TOC-5000 carbon analyzer, the concentrations of dissolved $\mathrm{N}_{\text {tot }}, \mathrm{NH}_{4}^{+}$and $\mathrm{NO}_{3}^{-}$with a Foss Tecator Fiastar 5000 FIA-analyzer, the concentrations of $\mathrm{P}_{\text {tot }}$ with a plasma emission spectrophotometer (Iris AP HRDUO-ICP), and the concentrations of $\mathrm{PO}_{4}{ }^{3-}$ spectrophotometrically with UV-240 JPC Shimadzuspectrofotometer. All water chemistry analyses were performed in the accredited laboratories of the former Finnish Forest Research Institute (presently Natural Resources Institute Finland). Statistical differences between the SS and nutrient concentrations and loads from inflow and outflow water were analyzed with paired t-tests, which were performed using the SPSS 22.0 statistical tool package (SPSS Inc.). Test results were considered significant if $p<0.05$.

\section{Results and Discussion}

The mean annual temperature at Tunkiosalonneva during 2009-2010 was only slightly lower than the long term average of $1987-2017$ (3.0 and $3.8^{\circ} \mathrm{C}$, respectively). However, the temperature of July in 2010 was clearly higher than the long term average of 1987-2017, but on the other hand, the temperature of January in 2010 was clearly lower than the long term average of 1987-2017 (Figure 2). The annual cumulative precipitation during 2009-2010 was nearly same than the long term average of 1987-2017 (46.8 and $50.5 \mathrm{~mm}$, respectively). However, the precipitation in June 2010 was clearly higher than the long term average of 1987 2017 , but in January oppositely clearly lower than the long term average of 1987-2017 (Figure 2).

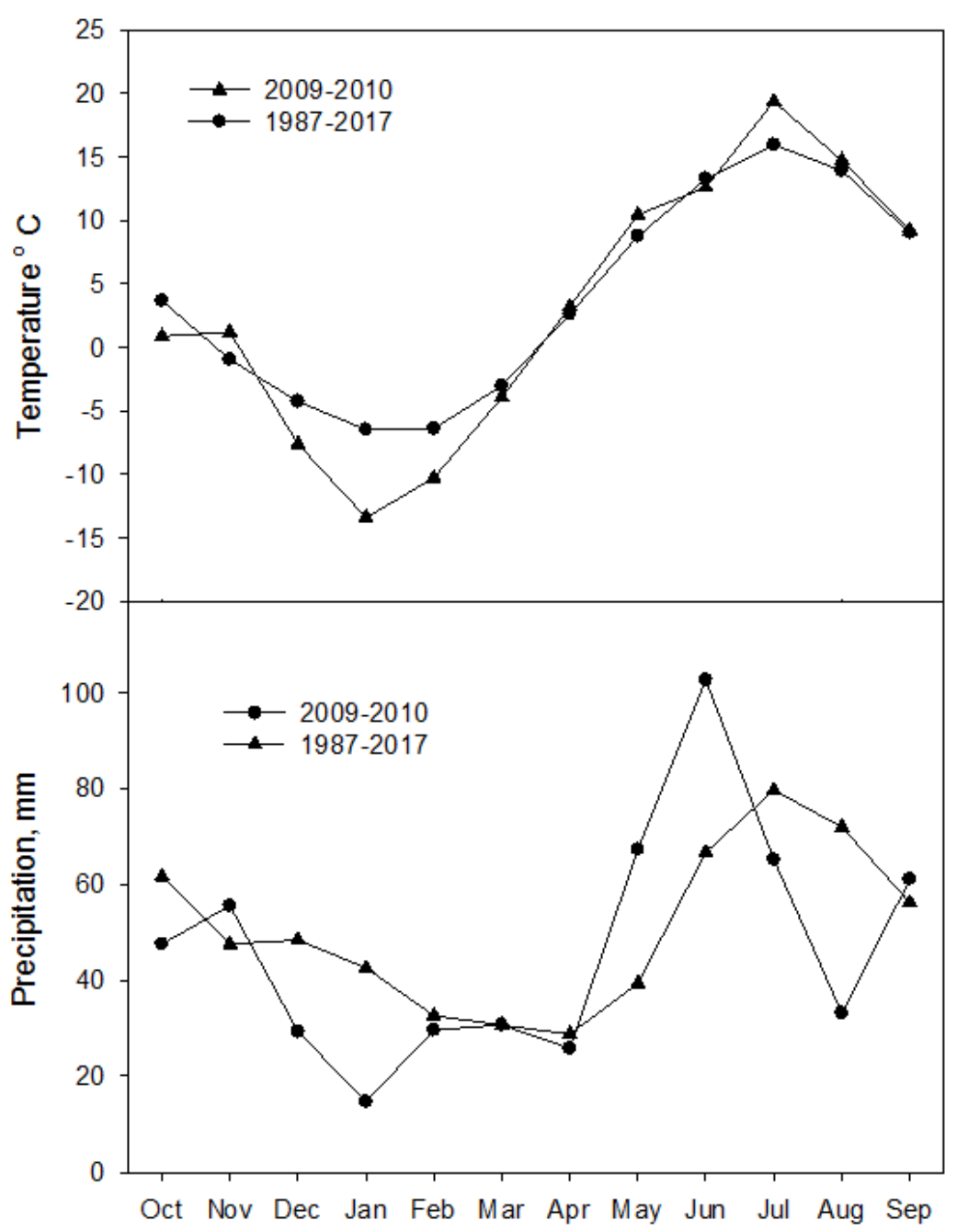

Figure 2. Mean air temperature and monthly precipitation at Tunkiosalonneva from October to October in 2009-2010 and as 30-year average 1987-2017.

Runoff rates varied rather largely within the study year (Figure 3), which is the normal phenomenon in the middle boreal climate type. The observed peak runoff rate was rather high, $3.2 \mathrm{l} \mathrm{s}^{-1} \mathrm{ha}^{-1}$, and occurred during the spring flood season in early April (Figure 3). On the other hand, in midwinter there was no existing runoff from the site (Figure 
3). Also some thunderstorm occasions with high precipitation in June caused rather high runoff rates, $1.91 \mathrm{~s}^{-1} \mathrm{ha}^{-1}$. However, in general, weather conditions during the study period can be considered as rather normal for Central Finland, and therefore there were observed no severe anomalies in the runoff data. Since the runoffs from the study site were rather normal, and since the study site was a typical middle boreal, nutrient-poor peatland, the results could probably be well generalized over the whole Southern and Central Finland.

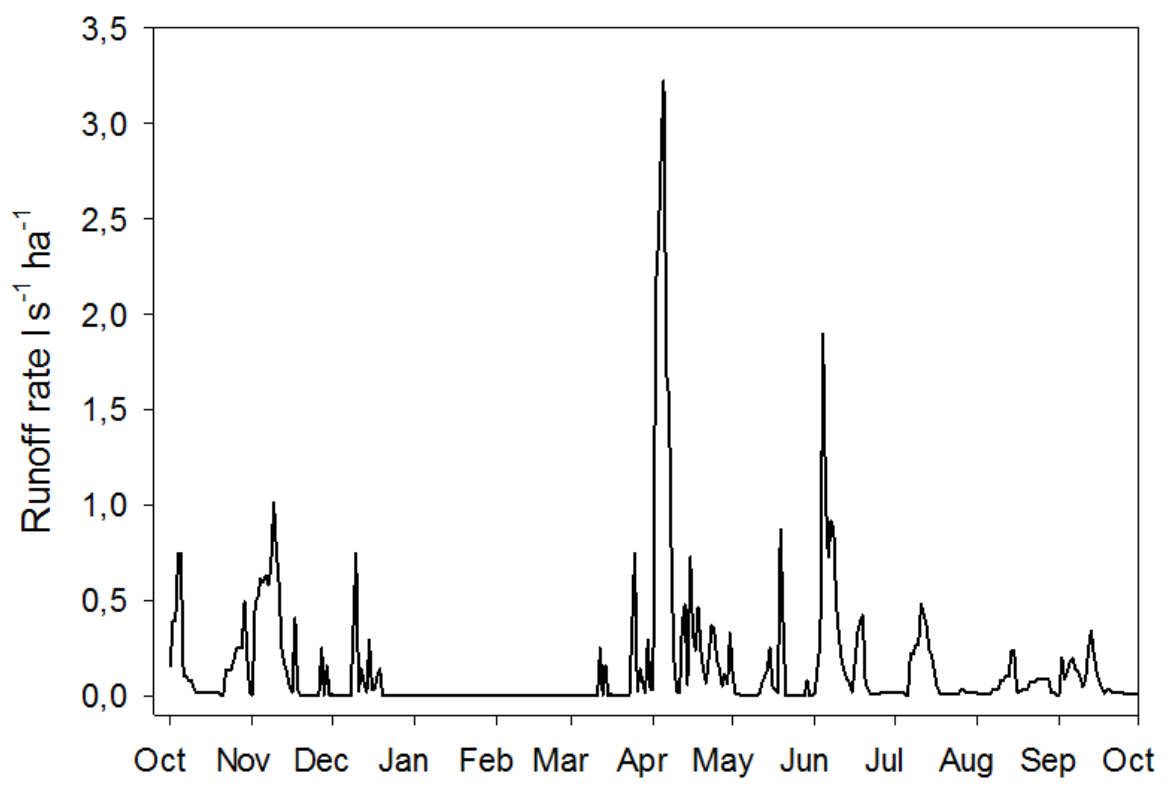

Figure 3. Runoff rates $\left(l s^{-1} h a^{-1}\right)$ at Tunkiosalonneva during October 2009-October 2010.

In this study, no significant differences $(p<0.05)$ between the concentrations of SS, DOC and nutrients in the inflow and in the outflow water were observed (Table 1). Because of the clear peak in runoff rates in springtime, also maximum SS, DOC and nutrient loads occurred during spring flood in early April. However, average annual loads of SS, DOC and nutrients followed the concentration of SS, DOC and nutrients in runoff water (Table 2), and therefore we observed no significant differences $(p<0.05)$ between the loads nor the concentrations of SS, DOC and nutrients.

Table 1. Average total concentrations of SS and DOC $\left(\mathrm{mg} \mathrm{l}^{-1}\right)$ and nutrients $\left(\mu \mathrm{g} l^{-1}\right)$ in the inflow and in the outflow water during October 2009-October 2010.

\begin{tabular}{lll}
\hline & Inflow & Outflow \\
\hline $\mathrm{SS}, \mathrm{mg} \mathrm{l}^{-1}$ & 3.0 & 3.2 \\
$\mathrm{DOC}, \mathrm{mg} \mathrm{l}^{-1}$ & 5.2 & 5.2 \\
$\mathrm{~N}_{\text {tot }}, \mu \mathrm{g} \mathrm{l}^{-1}$ & 540 & 545 \\
$\mathrm{NH}_{4}^{+}, \mu \mathrm{g} \mathrm{l}^{-1}$ & 72 & 68 \\
$\mathrm{NO}_{3}^{-}, \mu \mathrm{g} \mathrm{l}^{-1}$ & 18 & 13 \\
$\mathrm{P}_{\text {tot }}, \mu \mathrm{g} \mathrm{l}^{-1}$ & 14 & 16 \\
$\mathrm{PO}_{4}^{3-}, \mu \mathrm{g} \mathrm{l}^{-1}$ & 3 & 3 \\
\hline
\end{tabular}

Table 2. Average annual loads of SS and DOC $\left(\mathrm{kg} \mathrm{a}^{-1} \mathrm{ha}^{-1}\right)$ and nutrients $(g$ $\left.a^{-1} h^{-1}\right)$ caused by Sphagnum moss biomass harvesting during October 2009-October 2010.

\begin{tabular}{ll}
\hline Load & \\
\hline $\mathrm{SS}, \mathrm{kg} \mathrm{a}^{-1} \mathrm{ha}^{-1}$ & 1.0 \\
$\mathrm{DOC}, \mathrm{kg} \mathrm{a}^{-1} \mathrm{ha}^{-1}$ & 0.0 \\
$\mathrm{~N}_{\text {tot }}, \mathrm{g} \mathrm{a}^{-1} \mathrm{ha}^{-1}$ & 9.6 \\
$\mathrm{NH}_{4}^{+}, \mathrm{g} \mathrm{a}^{-1} \mathrm{ha}^{-1}$ & 0.0 \\
$\mathrm{NO}_{3}^{-}, \mathrm{g} \mathrm{a}^{-1} \mathrm{ha}^{-1}$ & 24.0 \\
$\mathrm{P}_{\text {tot }} \mathrm{g} \mathrm{a}^{-1} \mathrm{ha}^{-1}$ & -24.0 \\
$\mathrm{PO}_{4}^{3-}, \mathrm{g} \mathrm{a}^{-1} \mathrm{ha}^{-1}$ & -19.2 \\
\hline
\end{tabular}

In general, observed runoff rates in this study were of the rather similar magnitude as in the earlier studies from Finnish pristine mires, and also from peatlands drained for forestry [14, 23-27]. However, peak runoff rates may be higher on peatlands drained for forestry compared to the peak runoff rates of pristine mires [14, 23-27]. In this study, the observed peak runoff rate was $3.2 \mathrm{l} \mathrm{s}^{-1} \mathrm{ha}^{-1}$ while the annual mean runoff rate was $0.2 \mathrm{l} \mathrm{s}^{-1} \mathrm{ha}^{-1}$, thus the peak runoff rate was only approximately 21 -fold compared to the annual mean. Also the concentrations of SS and nutrients observed in the runoff water in this study chiefly corresponded to the very low concentrations observed in pristine mires in Central Finland [14, 23, 24]. Although Tunkiosalonneva can be defined as a forestry drained peatland, the ditch network of the area was sparse and deteriorated, and therefore Tunkiosalonneva functioned hydrologically chiefly as a rather normal pristine mire in Central Finland [28]. Additionally, Sphagnum moss biomass harvesting without any kind of drainage before or during the harvesting operation did not cause any peak runoffs increasing bypass flows from the area, on the contrary of peat extraction or of forest drainage [14, 26, 27, 29]. It is known that the major part of SS and nutrient load from peatlands occurs during the peak runoffs $[14,23,24]$. Thus, the rareness of large peak runoffs from the Sphagnum moss biomass harvesting area due to the lack of new ditches is a one reason for the negligible effects on water quality. Probably the most important reason, however, is that during Sphagnum moss biomass harvesting only the uppermost, nutrient-poor $30 \mathrm{~cm}$ layer of the soil is harvested, and without drainage. Therefore only the very low amounts of SS and nutrients leached into 
the runoff water compared to the other land-uses of the peatlands $[14,16,23,26,29]$, thus resulting only negligible effects on water quality.

\section{Conclusions}

Although the peat reserves in Finland are very large, under high demand conditions the lack of good-quality horticultural peat may become a reality in the near future. The best areas for extraction of good-quality horticultural peat are large pristine raised bogs, which are also very valuable as nature sanctuaries. In southern Finland and, especially, in central Europe, the pristine mires that are large enough for extraction of horticultural peat are protected for nature conservation. Sphagnum biomass harvesting provides a renewable alternative constituent for growing media with negligible environmental effects in comparison to conventional production of horticultural white peat. For the most part, Sphagnum biomass harvesting is more closely comparable with sustainable forestry than with white peat production. However, this preliminary study was based on the only one intensively investigated study site and on the one study year after shallow Sphagnum moss biomass harvesting. Thus, the further research with more study sites and with the longer study period is needed in the near future achieving the more generalized results.

\section{Acknowledgements}

The Finnish Ministry of Agriculture and Forestry, which funded this project "Sphagnum moss production and use as a growth substrate in greenhouse crops", project number 7524, is gratefully acknowledged for making the project possible.

\section{References}

[1] Amha, Y., Bohne, H., Schmilewski, G., Picken, P. \& Reinikainen, O. (2010). Physical, chemical and botanical characteristics of peats used in the horticultural industry. European Journal of Horticultural Science, 75, 177-183.

[2] Reinikainen, O. \& Picken, P. (2008). Horticultural and environmental use of peat. In: Riitta Korhonen, Leila Korpela and Sakari Sarkkola (eds.), Finland - Fenland: pp. 189-195.

[3] Schmilewski, G. (2008). The role of peat in assuring the quality of growing media. Mires and Peat, 3, 1-8.

[4] Silvan, N., Jokinen, K., Näkkilä, J. \& Tahvonen, R. (2017). Swift recovery of Sphagnum carpet and carbon sequestration after shallow Sphagnum biomass harvesting. Mires and Peat, 20, 1-11.

[5] Kämäräinen, A., Simojoki, A., Linden, L., Jokinen, K. \& Silvan, N. 2018. Physical growing media characteristics of Sphagnum biomass dominated by Sphagnum fuscum (Schimp.) Klinggr. Mires and Peat, 21, 1-16.

[6] Elling, A. E. \& Knighton, M. D. (1984). Sphagnum moss recovery after harvest in a Minnesota bog. Journal of soil and water conservation, 39, 209-211.

[7] Whinam, J. \& Buxton, R. (1996). Sphagnum peatlands of
Australasia: an assessment of harvesting sustainability. Biological conservation, 82, 21-29.

[8] Whinam, J., Hope, G. S., Clarkson, B. R., Buxton, R. P., Alspach, P. A. \& Adam, P. (2003). Sphagnum in peatlands of Australasia: Their distribution, utilisation and management. Wetlands Ecology and Management, 11, 37-49.

[9] Diaz, M. F., Tapia, C., Jimenez, P. \& Bacigalupe, L. (2012). Sphagnum magellanicum growth and productivity in Chilean anthropogenic peatlands. Revista Chilena de Historia Natural, 85, 513-518.

[10] Quinty, F. \& Rochefort, L. (2003). Peatland Restoration Guide, second edition. Canadian Sphagnum Peat Moss Association and New Brunswick Department of Natural Resources and Energy. Quebec, Canada.

[11] Gaudig, G. \& Joosten, H. (2002). Peat moss (Sphagnum) as a renewable resource -an alternative to Sphagnum peat in horticulture. In G. Schmilewski and L. Rochefort (eds.), Peat in horticulture. Quality and environmental challenges. International Peat Society, Jyväskylä, pp. 117-125.

[12] Laine, J., Vasander, H., Hotanen, J.-P., Nousiainen, H., Saarinen, M. \& Penttilä, T. (2012). Suotyypit ja turvekankaat - opas kasvupaikkojen tunnistamiseen. Metsäkustannus. 160 pp. (In Finnish).

[13] Clausen J. C. \& Brooks, K. N. (1983). Quality of runoff from Minnesota peatlands. Water Research Bulletin, 19, 763-767.

[14] Sallantaus T. (1983). Turvetuotannon vesistökuormitus. Reports of the Ministry of Trade and Industry. 122 pp. [In Finnish with English abstract].

[15] Selin P., Marja-aho J. and Madekivi O. (1994). Aqua Peat 95, new methods for purifying the run-offs of peat extraction areas. Ministry of Trade and Industry, Reviews B182: 195 pp. [In Finnish with English abstract].

[16] Kløve B. (1997). Leaching of nitrogen, phosphorus and organic matter from a plough-drained peatland in Central Finland. In: Kløve, B. 1997. Environmental impact of peat mining, development of storm-water treatment methods. Ph. D. Thesis, Lund University, 159 pp.

[17] Hynynen J., Palomäki A., Granberg K. \& Bibiceanu S. (1994). Turvetuotannon biologiset pitkäaikaisvaikutukset pienissä ruskeavetisissä metsäjärvissä. Reports of the Institute for Environmental Research 145: 1-37. [In Finnish with English abstract].

[18] Cruickshank M. M., Tomlinson R. W., Bond D., Devine P. M. \& Edwards C. J. W. (1995). Peat extraction, conservation and the rural economy in Northern Ireland. Appl. Geography 15: 365-383.

[19] Laine A. (2001). Restoring salmonid stocks in boreal rivers. Problems of passage at migratory obstructions and landderived loading in production areas. Publication of University of Oulu. 1-35.

[20] Laine A. \& Heikkinen K. (2000). Peat mining increasing finegrained organic matter on the riffle beds of boreal streams. Arch. Hydrobiol. 148: 9-24.

[21] Näkkilä, J., Silvan, N., Jokinen, K., Särkkä, L. \& Tahvonen, R. (2015). Rahkasammalen tuotanto ja käyttö kasvihuonekasvien kasvualustana. MMM-Makeraloppuraportti. 16 pp. (In Finnish). 
[22] Silvan, N., Silvan, K., Näkkilä, J., Tahvonen, R. \& Reinikainen, O. (2012). Renewability, use and properties of Sphagnum biomass for growing media purposes. In: Proceedings of the 14th International Peat Congress, session Sphagnum Farming, extended abstract number 55.

[23] Sallantaus T. (1986). Soiden metsä-ja turvetalouden vesistövaikutukset-kirjallisuuskatsaus. Reports of the Ministry of Agriculture and Forestry. 203 pp. [In Finnish].

[24] Mattsson, T., Finer, L., Kortelainen, P. \& Sallantaus, T. 2003. Brookwater quality and background leaching from unmanaged forested catchments in Finland. Water, Air, and Soil Pollution, 147, 275-297.

[25] Joensuu S. (2002). Effects of ditch network maintenance and sedimentation ponds on export loads of suspended solids and nutrients from peatland forests. Ph. D. Thesis, Helsinki University, $144 \mathrm{pp}$.

[26] Nieminen, M., Ahti, E., Koivusalo, H., Mattsson, T., Sarkkola,
S. \& Lauren, A. 2010. Export of suspended solids and dissolved elements from peatland areas after ditch network maintenance in South-Central Finland. Silva Fennica, 44 (1), $39-49$.

[27] Nieminen, M., Palviainen, M., Sarkkola, S., Lauren, A., Marttila H. \& Finer, L. 2017. A synthesis of the impacts of ditch network maintenance on the quantity and quality of runoff from drained boreal peatland forests. Ambio, DOI 10.1007/s13280-017-0966-y.

[28] Tahvanainen, T. 2004. Water chemistry of mires in relation to the poor-rich vegetation gradient and contrasting geochemical zones of the North-Eastern Fennoscandian shield. Folia geobotanica, 39, 353-369.

[29] Silvan, N., Silvan, K. \& Laine, J. (2010). Reduced detrimental effects on watercourses using the new excavation-drier method for energy peat production. Boreal Environment Research, 15, 347-356. 